\section{CITAÇÃO}

Magalhães, A. \& Duarde, L. V.(2020)

$\mathrm{O}$ lado invisível das rochas,

Rev. Ciência Elem., V8(01):012.

10.24927/rce2019.012

\section{EDITOR}

José Ferreira Gomes,

Universidade do Porto

\section{RECEBIDO EM}

15 de janeiro de 2020

\section{ACEITE EM}

15 de janeiro de 2020

\section{PUBLICADO EM}

28 de fevereiro de 2020

\section{COPYRIGHT}

(C) Casa das Ciências 2020.

Este artigo é de acesso livre, distribuído sob licença Creative

Commons com a designação CC-BY-NC-SA 4.0, que permite a utilização e a partilha para fins não comerciais, desde que citado o autor e a fonte original do artigo.

rce.casadasciencias.org

\title{
O lado invisível das rochas
}

Toda a imagem é um enigma que cristaliza num ponto singular o movimento perpétuo do Mundo. Mesmo que de rochas estejamos a falar, sabem bem os nossos colegas geólogos que a acinesia é ilusória. A relatividade do movimento assenta sempre numa escala espacial. No caso particular desta imagem a ausência de uma referência dimensional desorienta o observador no espaço levando à perda de objetividade na sua interpretação. Numa primeira abordagem vi nela uma linda fotografia de satélite de uma região costeira pintalgada por alvas formações nebulosas de onde se destaca uma ilha num círculo quase perfeito. Por fim, a leitura da explicação dada pelo autor provocou-me uma queda vertiginosa de 9 ou 10 ordens de grandeza para a escala das imagens micrométricas de rochas obtidas sob luz polarizada que, quase sempre, se revelam assaz belas.

Com este apontamento geológico, fica aqui provado que a Ciência não se resume a uma visão fria e utilitária do Mundo e pode despertar-nos sentimentos de outras dimensões.

Alexandre Lopes Magalhães

DQB/ Universidade do Porto
A base do conhecimento geológico alicerça-se nas rochas. 0 seu estudo mais clássico, independentemente do tipo de litologia, assenta na análise petrográfica que envolve observações à escala microscópica, tirando partido das características óticas dos diversos minerais em lâmina delgada. É o caso da presente fotomicrografia (sem escala), obtida sob luz polarizada, que combina duas massas minerais, bem distintas, de uma rocha formada em ambiente sedimentar. A de cor acastanhada, particularmente cristalina, corresponde a um carbonato de cálcio e magnésio, a dolomite, normalmente tido como um mineral "problemático" quanto à sua génese. A massa acinzentada, materializada por diferentes graus de cristalinidade, está associada a uma fase de precipitação siliciosa, com características semelhantes às do quartzo. A análise da imagem, auxiliada pelo manuseamento de todas as potencialidades do microscópio petrográfico, mostra uma combinação de processos sedimentares algo complexos, entre a deposição e a fase subsequente, a diagénese. $\mathrm{E}$ o que falta dizer (...).

Luís Vítor Duarte

MARE/ DCT/ Universidade de Coimbra 


\section{REVISTA DE CIÊNCIA ELEMENTAR}

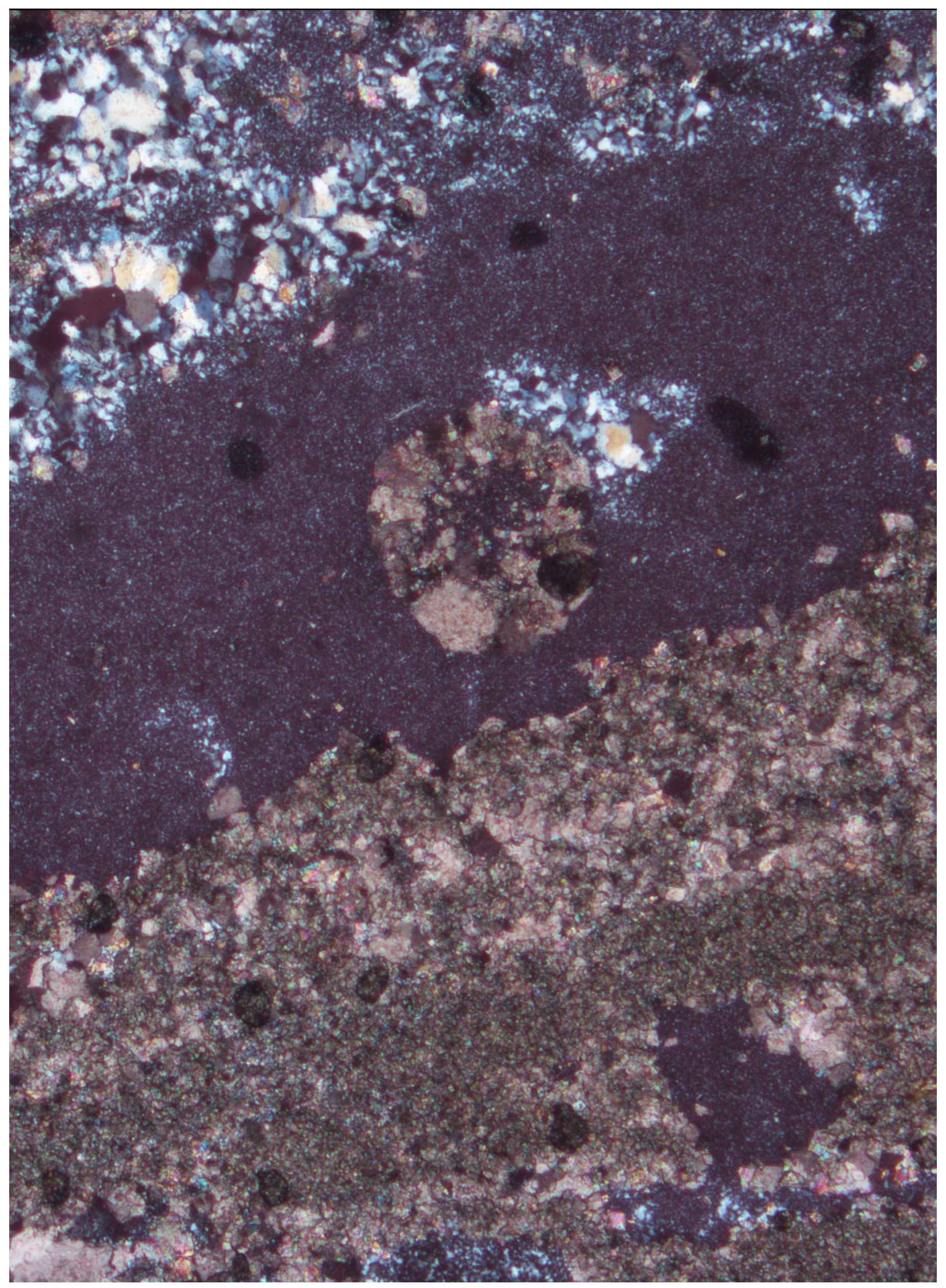

